\title{
Summary of Natural Resources That Potentially Influence Human Intrusion at the Area 5 Radioactive Waste Management Site, Nevada Test Site, Nye County, Nevada
}

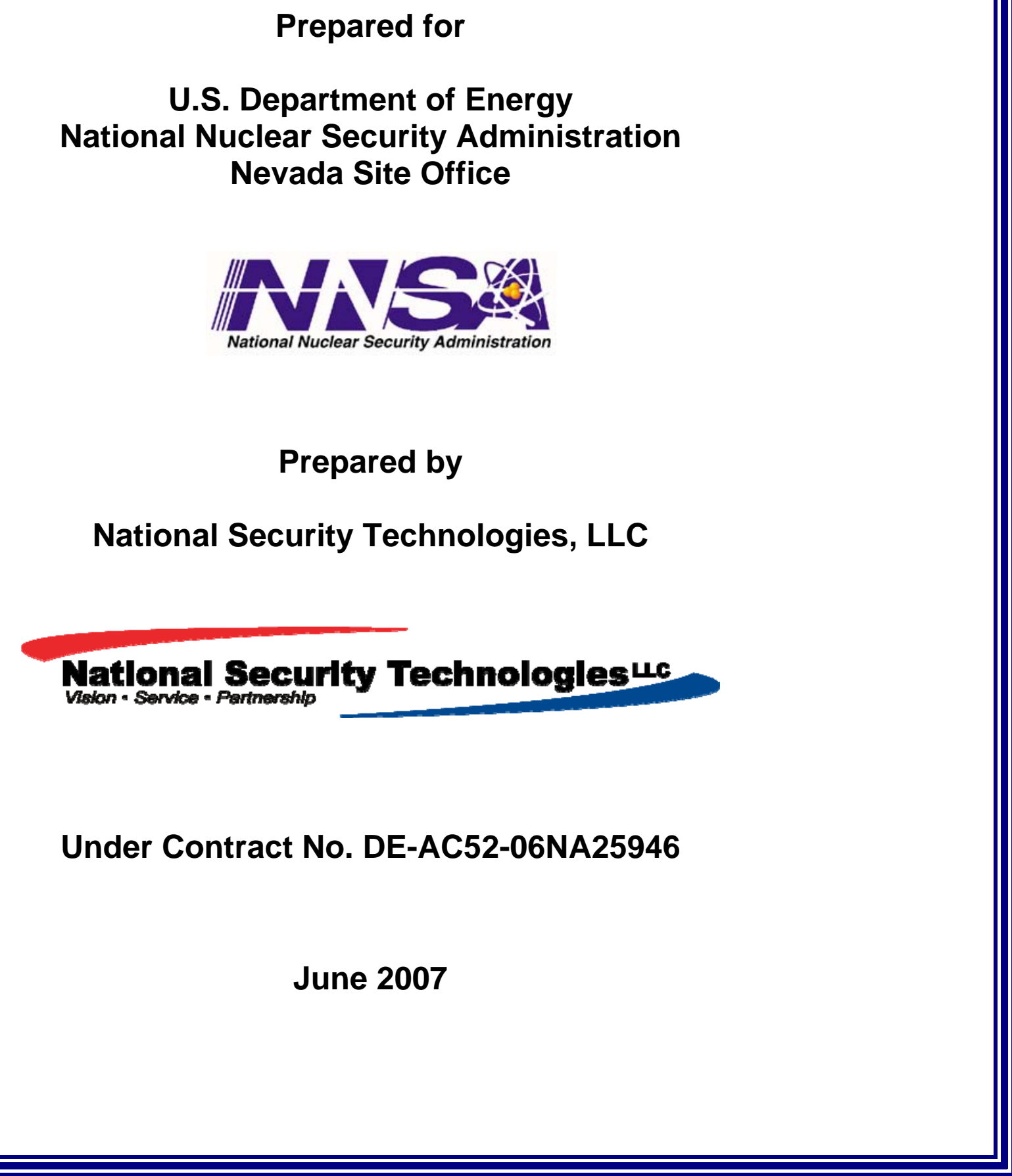




\title{
DISCLAIMER
}

Reference herein to any specific commercial product, process, or service by trade name, trademark, manufacturer, or otherwise does not necessarily constitute or imply its endorsement, recommendation, or favoring by the United States Government or any agency thereof or its contractors or subcontractors.

Available for sale to the public, in paper, from:

\author{
U.S. Department of Commerce \\ National Technical Information Service \\ 5285 Port Royal Road \\ Springfield, VA 22161 \\ Phone: (800) 553-6847 \\ Fax: (703) 605-6900 \\ E-mail: orders@ntis.gov \\ Online Ordering: http://www.ntis.gov/ordering.htm
}

Available electronically at http://www.osti.gov/bridge

Available for a processing fee to the U.S. Department of Energy and its contractors, in paper, from:

U.S. Department of Energy

Office of Scientific and Technical Information

P.O. Box 62

Oak Ridge, TN 37831-0062

Phone: (865) 576-8401

Fax: (865) 576-5728

E-mail: reports@adonis.osti.gov 


\title{
Summary of Natural Resources That Potentially Influence Human Intrusion at the Area 5 Radioactive Waste Management Site, Nevada Test Site, Nye County, Nevada
}

\author{
Prepared for \\ U.S. Department of Energy \\ National Nuclear Security Administration \\ Nevada Site Office

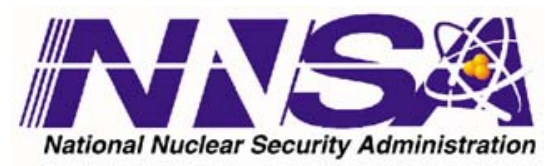

Prepared by

National Security Technologies, LLC

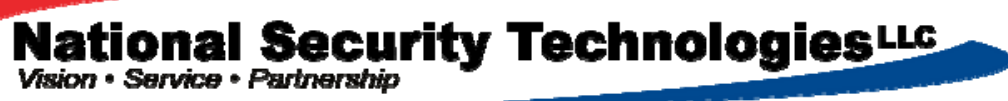

Under Contract No. DE-AC52-06NA25946

June 2007 
This Page Intentionally Left Blank 


\section{ABSTRACT}

In 1993, Raytheon Services Nevada completed a review of natural resource literature and other sources to identify potentially exploitable resources and potential future land uses near the Area 5 Radioactive Waste Management Site (RWMS) of the Nevada Test Site (NTS), Nye County, Nevada, that could lead to future inadvertent human intrusion and subsequent release of radionuclides to the accessible environment. National Security Technologies, LLC, revised the original limited-distribution document to conform to current editorial standards and U.S. Department of Energy requirements for public release.

The researchers examined the potential for future development of sand, gravel, mineral, petroleum, water resources, and rural land uses, such as agriculture, grazing, and hunting. The study was part of the performance assessment for Greater Confinement Disposal boreholes.

Sand and gravel are not considered exploitable site resources because the materials are common throughout the area and the quality at the Area 5 RWMS is not ideal for typical commercial uses. Site information also indicates a very low mineral potential for the area. None of the 23 mining districts in southern Nye County report occurrences of economic mineral deposits in unconsolidated alluvium.

The potential for oil and natural gas is low for southern Nye County. No occurrences of coal, tar sand, or oil shale on the NTS are reported in available literature.

Several potential future uses of water were considered. Agricultural irrigation is impractical due to poor soils and existing water supply regulations. Use of water for geothermal energy development is unlikely because temperatures are too low for typical commercial applications using current technology. Human consumption of water has the most potential for cause of intrusion. The economics of future water needs may create a demand for the development of deep carbonate aquifers in the region. However, the Area 5 RWMS is not an optimal location for extraction of groundwater from the deep carbonate aquifer.

Grazing and hunting are unlikely to be potential causes for inadvertent human intrusion into waste areas because of vegetation characteristics and lack of significant game animal populations. 
This Page Intentionally Left Blank 


\section{EXECUTIVE SUMMARY}

A limited study was conducted at the Area 5 Radioactive Waste Management Site (RWMS) of the Nevada Test Site (NTS), Nye County, Nevada, as part of the performance assessment for Greater Confinement Disposal boreholes. The main objective of the study was to identify potentially exploitable resources and land uses near the RWMS that could lead to inadvertent human intrusion and subsequent release of radionuclides to the accessible environment. Sand and gravel, mineral, petroleum, and water resources, and alternative land uses such as agriculture, grazing, and hunting were evaluated.

Sand and gravel are not considered exploitable site resources because the materials are common throughout the area and the quality is not ideal. Site information also indicates a very low mineral potential for the area. None of the 23 mining districts in southern Nye County report occurrences of economic mineral deposits in unconsolidated alluvium.

The potential for oil and natural gas is low for southern Nye County. No occurrences of coal, tar sand, or oil shale on the NTS were found in the literature.

Three potential uses of water are discussed. Agricultural irrigation is not a practical consideration, due to poor soils and existing water regulations. Additionally, because temperatures are too low for typical commercial applications using current technology, the use of water for commercial geothermal energy development is also not a consideration. Human consumption of water has the most potential for cause of intrusion. The economics of future water needs may create a demand for the development of deep carbonate aquifers in the region; however, the Area 5 RWMS is not an optimal location for extraction of groundwater from the deep carbonate aquifer.

Grazing and hunting are unlikely to be potential causes for inadvertent human intrusion into waste areas because of vegetation characteristics and lack of significant game-animal populations. 
This Page Intentionally Left Blank 


\section{PREFACE}

National Security Technologies, LLC (NSTec), under contract to the U.S. Department of Energy (DOE), National Nuclear Security Administration Nevada Site Office (NNSA/NSO), is conducting closure planning activities for a portion of the Area 5 Radioactive Waste Management Site (RWMS) at the Nevada Test Site (NTS). The Area 5 RWMS has been studied extensively over the past two decades. Much characterization and performance assessment of the Area 5 RWMS site was completed by previous contractors and documented in reports with limited distribution. To support closure planning, NSTec is preparing several of these limited-distribution reports for approval for public release so that they will be more broadly accessible.

In 1993, Raytheon Services Nevada prepared Summary of Natural Resources that Potentially Influence Human Intrusion at the Area 5 Radioactive Waste Management Site, DOE/Nevada Test Site, Nye County, Nevada for the DOE under Contract DE-AC08-91NV10833. Authors of the August 1993 report were D. L. Gustafson, S. E. Rawlinson, and J. J. Miller. The study was performed as part of the performance assessment of the Greater Confinement Disposal (GCD) boreholes located within the Area 5 RWMS. The report identifies natural resources and conditions that might attract digging, drilling operations, or other intrusive activities in the vicinity of the Area 5 RWMS in the future.

NSTec made minor revisions to the 1993 Raytheon Services Nevada edition to conform to current editorial standards of the NNSA/NSO and to meet current security requirements for public release. The site description in Section 2.0 and the first two location map figures have been updated to reflect current NTS boundaries and site features. The abstract was added to meet requirements for electronic distribution on the DOE Office of Scientific and Technical Information (OSTI) Information Bridge public website. The report has not otherwise been significantly updated. This 2007 NSTec edition has been reviewed and approved by one of the principal authors of the original 1993 report.

This report documents one of many studies contributing to the performance assessment of the Area 5 RWMS. Performance assessments are ongoing studies required under DOE Order 435.1-1, "Radioactive Waste Management”; and DOE Manual 435-1. Further information on studies of the Area 5 RWMS and the natural resources of the NTS are available through OSTI (http://www.osti.gov/bridge/index.jsp).

At the Area 5 RWMS, the physical and natural site conditions, continued compliance with DOE orders and federal regulations, and existing NNSA/NSO NTS procedures will mitigate potential inadvertent intrusions by members of the public into the radioactive waste for many years, even after active institutional control of the NTS by government is likely to end. 
This Page Intentionally Left Blank 


\section{CONTENTS}

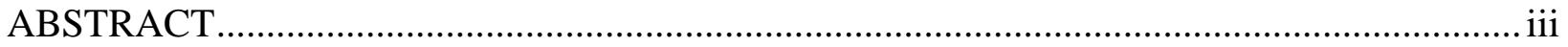

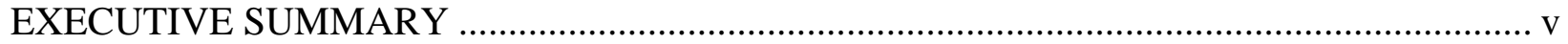

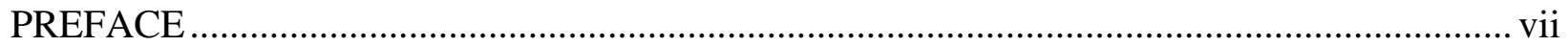

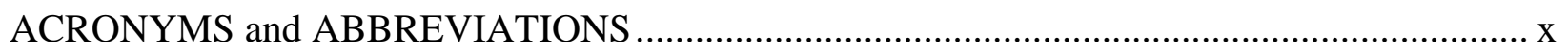

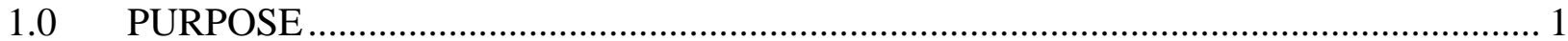

2.0 RADIOACTIVE WASTE MANAGEMENT SITE DESCRIPTION

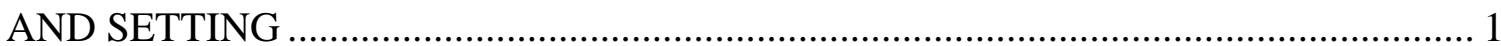

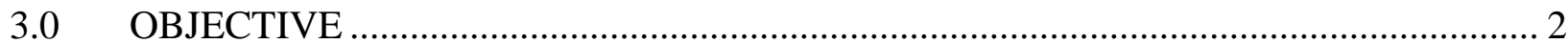

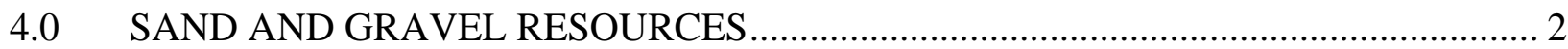

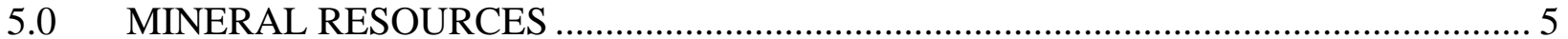

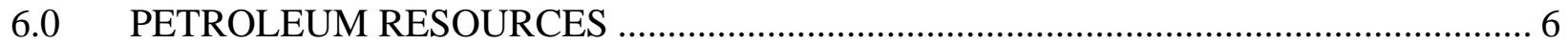

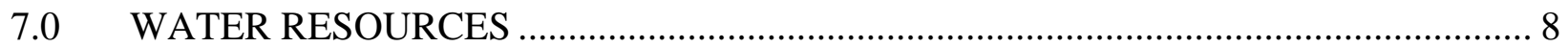

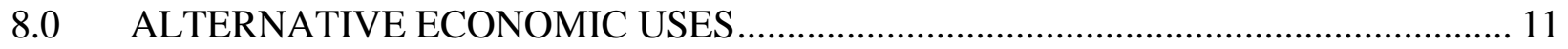

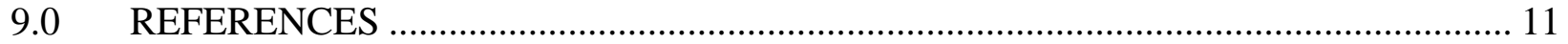

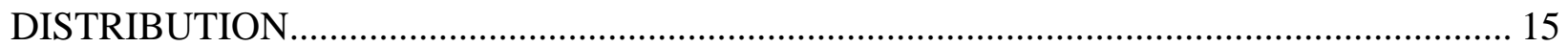

\section{List of Figures}

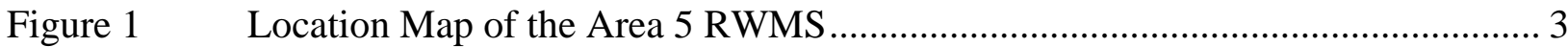

Figure 2 Map of Frenchman Flat Area ....................................................................... 4

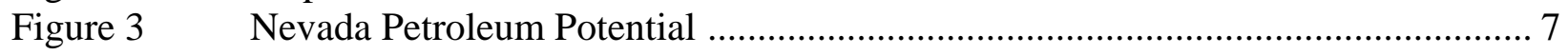

Figure $4 \quad$ Great Basin Carbonate Rock Province ........................................................ 10

Plate $1 \quad$ Map of Oil and Gas Developments in Nevada and Mining Activities

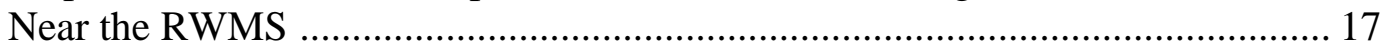




\title{
ACRONYMS and ABBREVIATIONS
}

\author{
DOE \\ U.S. Department of Energy \\ $\mathrm{ft}$ \\ feet/foot \\ GCD \\ Greater Confinement Disposal \\ $\mathrm{km}$ \\ kilometer(s) \\ $\mathrm{m}$ \\ meter(s) \\ NNSA/NSO \\ National Nuclear Security Administration Nevada Site Office \\ NSTec \\ National Security Technologies, LLC \\ NTS \\ Nevada Test Site \\ OSTI \\ Office of Scientific and Technical Information \\ RWMS \\ Radioactive Waste Management Site
}




\subsection{PURPOSE}

At the request of the U.S. Department of Energy (DOE), Raytheon Services Nevada performed a limited study at the Area 5 Radioactive Waste Management Site (RWMS) of the Nevada Test Site (NTS), Nye County, Nevada, to determine natural resources that potentially influence human intrusion. This limited study was conducted to support the scenario development activities of the performance assessment for Greater Confinement Disposal (GCD) boreholes.

\subsection{RADIOACTIVE WASTE MANAGEMENT SITE DESCRIPTION AND SETTING}

Area 5 RWMS is approximately 110 kilometers $(\mathrm{km})$ (68 miles [mi]) northwest of Las Vegas, Nevada (Figure 1). The GCD boreholes are in the southeast quadrant of a designated 296-hectare (732-acre) waste disposal area. The boreholes are located near shallow waste disposal pits and trenches. The GCD boreholes are inactive. DOE discontinued waste disposal and classified material storage operations in the GCD in 1989. The level of the top of the packages placed in the GCD boreholes is at least 21 meters (m) (70 feet [ft]) below ground surface and most of the boreholes which received packages have already been backfilled with native soil to ground surface. Four of the boreholes were not used and are empty.

Waste-burial operations in the southeast quadrant of the Area 5 RWMS are expected to be complete in 2010. Many of the shallow waste trenches and pits are already full and the waste in these has been covered under approximately $2.4 \mathrm{~m}(8 \mathrm{ft})$ of interim soil cover. The closure covers in this quadrant will be integrated. The final engineered cover is scheduled to be constructed over the GCD boreholes, and the shallow trenches and pits in the southeast quadrant, in 2011. Closure plans approved by DOE will detail the many passive and active institutional controls, site conditions, and design features which help protect the integrity of the wastedisposal facility post closure. The performance assessment of the GCD boreholes must meet the Assurance Requirements of Title 40 Code of Federal Regulations 191. Potential for inadvertent intrusions by members of the public is taken into consideration in the siting, operation, and closure of radioactive-waste disposal sites.

The Area 5 RWMS is located in northern Frenchman Flat, a topographically closed basin (Figure 2). The uppermost stratigraphic unit consists of alluvium. The alluvium is underlain by interbedded ash-fall and ash-flow tuffs. The bedded tuffs act as an aquitard. The ash-flow tuff is underlain by Paleozoic carbonate rocks. During 2005, depth to water in the uppermost valley fill aquifer was about $235.8 \mathrm{~m}(774 \mathrm{ft})$ at monitoring well UE5PW-1 at the southeast corner of the facility (National Security Technologies, LLC [NSTec], 2006). The primary regional aquifer is in the carbonate rocks, far below. On the basis of recent 3-D seismic reflection data (Bechtel Nevada [BN], 2006), the upper surface of the underlying carbonate rocks is about 2,100 $\mathrm{m}$ $(6,900 \mathrm{ft})$ below the ground surface of the Area 5 RWMS.

The site is situated at the intersection of several alluvial fans composed of boulders, gravel, and fine sediments eroded from surrounding mountains. This sediment has been transported and deposited primarily by intermittent streams. Particle-size data from the Science Trench Boreholes study adjacent to the site indicate the upper alluvium is well-graded sand with silt and gravel (Reynolds Electrical \& Engineering Co., Inc. [REECo], 1993). 
There are no permanent natural surface waters in Frenchman Flat. Water briefly accumulates on Frenchman Playa approximately $6.4 \mathrm{~km}(4 \mathrm{mi})$ southeast. There are also a few small artificial impoundments (BN, 2006). Evaporation rates in Frenchman Flat are high. Average annual potential evapotranspiration at the Area 5 RWMS (calculated using local meteorology data) is approximately 13 times the annual average precipitation (Desotell et al., 2006). The nearest spring is Cane Spring, about $14.4 \mathrm{~km}$ (9 mi) southwest of the Area 5 RWMS.

\subsection{OBJECTIVE}

The main objective of this study is to identify and quantify potentially exploitable resources near the RWMS that could lead to inadvertent human intrusion and possible release of radionuclides to the accessible environment. Identified candidate resources include sand, gravel, minerals, petroleum, water, and other land use considerations such as agriculture, grazing, and hunting.

\subsection{SAND AND GRAVEL RESOURCES}

The mid-alluvial fan location of the RWMS suggests that sand and gravel might be available in sufficient quantities to be viable resources. Alluvial fans are typically excellent sources of these resources. However, additional to availability, a viable resource must be of the appropriate quality and be in demand. These last two factors are likely to preclude commercial mining of sand and gravel from the RWMS area.

Waste disposal trenches and pits at the RWMS expose sediments to a depth of roughly $8 \mathrm{~m}$ (26 ft), approximately half the distance that might be excavated in exploiting sand and gravel resources. A log of a nearby GCD borehole (Gustafson et al., 1993) indicates that the trench and pit exposures are representative of deeper sediments. Both fine- and coarse-grained sediments are present in discontinuous beds. Samples of specific beds have been collected and analyzed for grain size. Collected samples have generally been small, and consequently those of coarse beds are probably not representative. Descriptions of the beds and analytical results are given in Snyder et al. (1993).

In general, these beds are composed of sand and gravel, with gravel fractions generally being pebbles with lesser amounts of cobbles. The quantity of these materials could be considered viable resources. However, limited sampling of the excavations within the RWMS indicate that the gravels are dominantly pyroclastic volcanic rocks (72 percent), with lesser amounts of quartzites (16 percent), carbonates (10 percent), and others (2 percent) (Snyder et al., 1993). Drilling data from the three pilot wells near the Area 5 RWMS list volcanic rock compositions at depths to approximately $244 \mathrm{~m}$ (800 ft) as ranging from 90 to 100 percent, based on core samples less than 7.62 centimeters (3 inches) in diameter (REECo, 1993). The pyroclastic volcanic rocks are friable and thus the quality of the sand and gravel near the Area 5 RWMS is not well suited for many commercial uses. 


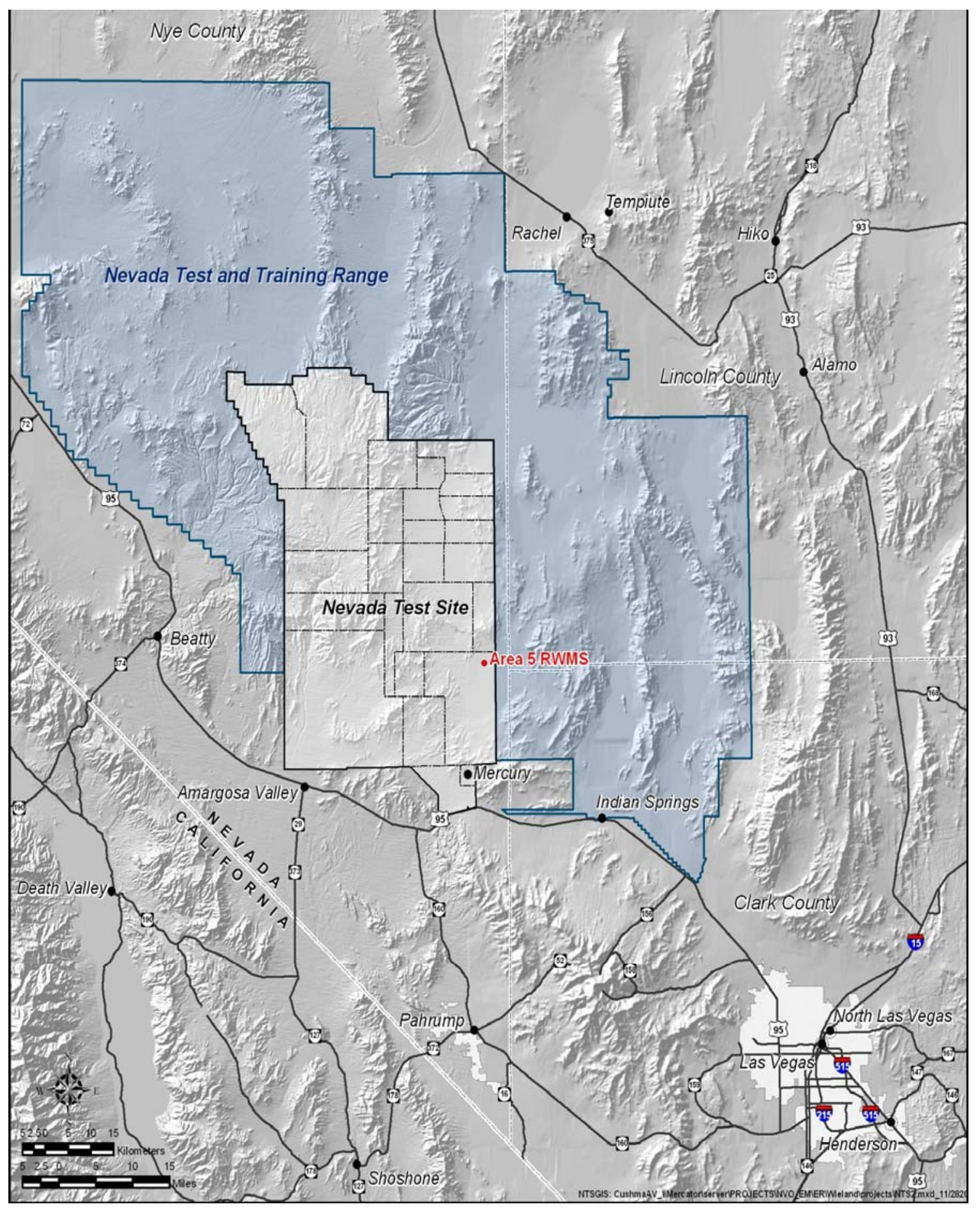

Figure 1

Location Map of the Area 5 RWMS 


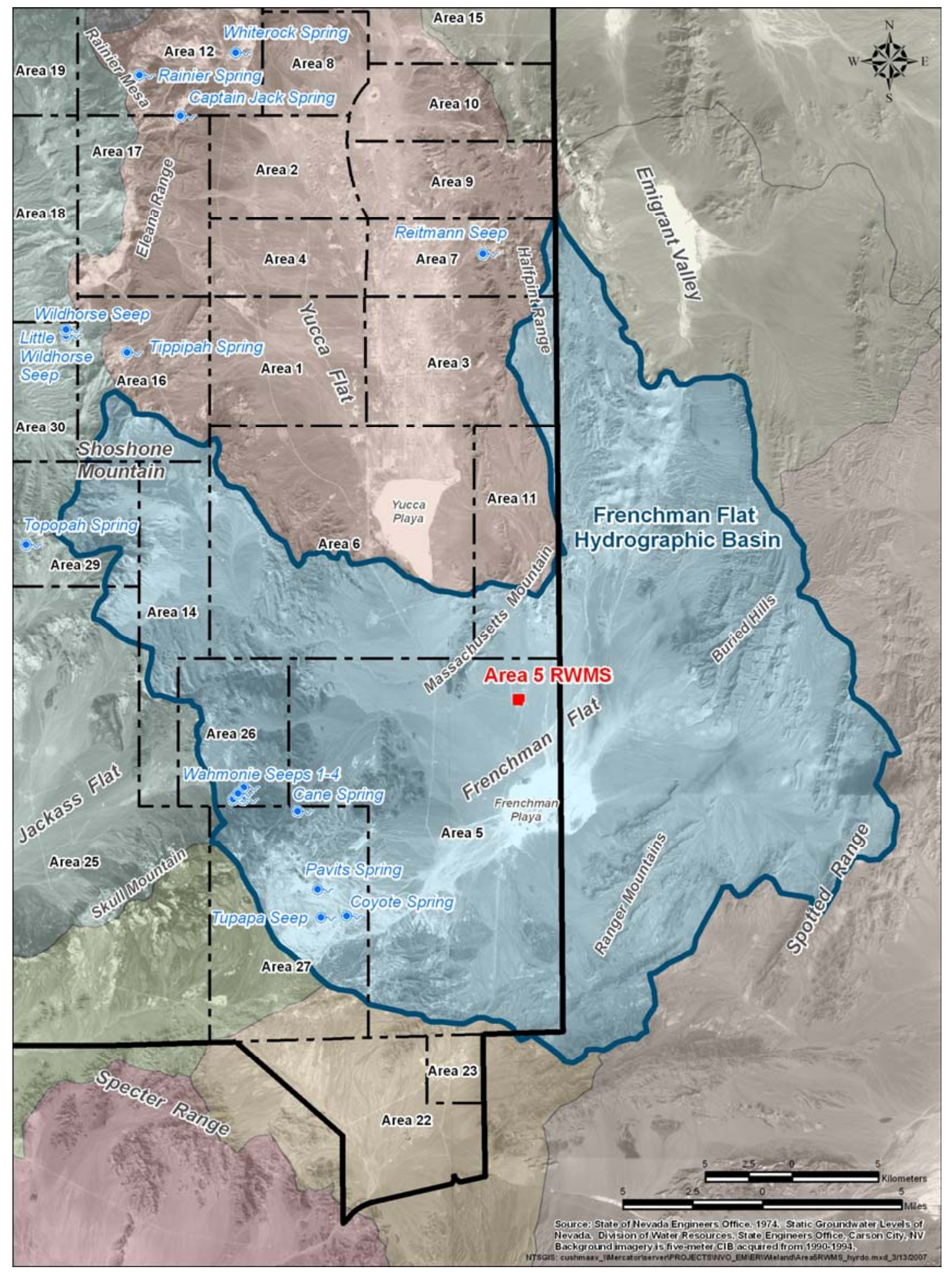

Figure 2

Map of Frenchman Flat Area 
Assuming that most sand and gravel resources are used for road base, building pads, and other fill structures, the demand for sand and gravel resources is tied to projected infrastructure and development. Projected infrastructure and development is proportional to population. The nearest population centers are relatively small and widely spaced. Projected populations within this area would likely not impact the NTS area because required resources are available nearby those centers.

Richard-Haggard (1983) concluded that the on-site population of the NTS will remain a function of activity at the site. Population projections are not available for the NTS. Proposed high-level nuclear waste disposal at Yucca Mountain, or emplacement of alternative uses of the NTS following cessation of nuclear testing, could increase the local population. Demand of sand and gravel resources that would impact the RWMS would have to be from activity in Area 5. Yucca Mountain is far from Area 5, and preferential use of Area 5 is entirely dependent on the proposed activity within Frenchman Flat. Sand and gravel resources within Area 5 are probably of better quality on the southern side of the basin where carbonate rocks compose a higher percentage of the gravel than near the RWMS. Thus demand for sand and gravel near the RWMS is probably low.

Considering the moderate quality of gravel in Area 5 and the probable limited demand for local sand and gravel, these resources are not considered to contribute greatly to the probability of inadvertent human intrusion at the RWMS.

\subsection{MINERAL RESOURCES}

Information from the site indicates a very low mineral potential. The literature does not record or show evidence of any historic mining activity within the boundaries of Frenchman Flat. In addition, field investigations have found no indication of any type of mining or prospecting excavations. The nearest recorded mineral deposits to the RWMS are the Mine Mountain District and the Wahmonie District (Plate 1). The Mine Mountain mining district (T. 11 S., R. 52 E.) is on Mine Mountain, $23 \mathrm{~km}$ (14 mi) northwest of the RWMS. All of the workings are in high-angle normal faults trending $\mathrm{N} .30^{\circ} \mathrm{E}$. in brecciated quartzite and silicified dolomite of the Devil's Gate Limestone in the upper plate of a thrust fault. Claim notices indicate exploration on Mine Mountain in 1928 (Cornwall, 1972). The Wahmonie mining district (T. 13 S., R. 51 E.) is $21 \mathrm{~km}(13 \mathrm{mi})$ southwest of the RWMS. This district was apparently discovered prior to 1905. Precious metals there occur in or along quartz veins in an area of hydrothermally altered latite to dacite lava flows, tuffs, and volcanic breccias of the Salyer and Wahmonie Formations (Cornwall, 1972). No site-specific information is available regarding precious or base metal potential in the tuffaceous units or Paleozoic rocks underlying Frenchman Flat. Determinations of potential for deeply buried mineral deposits under Frenchman Flat which could be minable under future economic conditions, or using new technologies, are not within the scope of this investigation. None of the 23 mining districts in southern Nye County reported the occurrences of economic mineral deposits in unconsolidated alluvium. However, geochemical analyses of the alluvium for precious metals could be the subject of future research.

Future exploration for zeolites, if the need arose, would center around unconsolidated surface deposits in alluvium (DOE, 1988). No attempt was made to quantify zeolites near the RWMS and the topic could be the subject of future research. Before effort is expended, place value of 
the resource should be considered. The estimated quantity of zeolites in the alluvial valley fill of the entire NTS is 150 trillion long tons (152 trillion metric tons) (DOE, 1988), thus the resource is not unique to the RWMS area.

\subsection{PETROLEUM RESOURCES}

Petroleum exploration in Nevada has been limited and, prior to the creation of the Nevada Oil and Gas Conservation Commission in 1953, drilling information is incomplete. However, available records do show that approximately 650 wells have been drilled in the state through November 1992. The first well drilled in Nevada for oil or gas was a dry hole drilled in Washoe County in 1907 (Garside et al., 1988). The highest concentration of wells is in the Railroad Valley area of northeastern Nye County, which is approximately $150 \mathrm{~km}$ (92 mi) north of the RWMS.

Through the end of 1992, six fields have been discovered in Railroad Valley. Productive areas of these fields vary from less than 2.5 to more than 10.4 square kilometers (less than 1.0 to more than 4.0 square miles $\left[\mathrm{mi}^{2}\right]$ ), and the depth of production ranges from approximately 1,220 to 2,130 $\mathrm{m}$ (4,000 to 7,000 ft) (Garside et al., 1988). Oil production from these fields is found in structural traps or a combination of structural-stratigraphic traps. Producing formations include Paleozoic limestones and dolomites, as well as Tertiary volcanics. The only oil production outside Railroad Valley is in the Blackburn Field discovered in 1982 approximately $193 \mathrm{~km}$ $(120 \mathrm{mi})$ north of Railroad Valley in Pine Valley, Eureka County. Production at Blackburn Field is from tuffs, tuffaceous sandstones, and fractured calcareous dolomites associated with a combination structural-stratigraphic trap (Garside et al., 1988).

The potential for oil and natural gas is rated low for southern Nye County in two Nevada Bureau of Mines and Geology reports (Garside et al., 1988; Castor et al., 1990). Figure 3 and Plate 1 are simplified views of this potential, based on the presence of source rocks and suitable maturity (Stewart and Carlson, 1978; Harris et al., 1980), and reported surface and subsurface hydrocarbon shows.

The nearest wells drilled for oil and gas to the RWMS are shown on Plate 1 (Garside et al., 1988). The Jayhawk Exploration Inc., Federal-Indian Springs No. 1 is located in Clark County, Nevada, approximately $50 \mathrm{~km}$ (31 mi) southeast of the site. This well was drilled in 1982 to a total depth of 1,685 m (5,583 ft). Two exploratory wells drilled in southern Nye County in 1991 by Felderhoff Production Company (the Felderhoff-Federal No. 5-1 and No. 25-1) located approximately $48 \mathrm{~km}$ (30 mi) southwest of the site, were drilled to total depths of $447 \mathrm{~m}$ $(1,468 \mathrm{ft})$ and 1,524 m (5,000 ft), respectively. The Myjo Oil Corporation Coffer No. 1, also located in southern Nye County, was drilled at a location approximately $64 \mathrm{~km} \mathrm{(40} \mathrm{mi)} \mathrm{west} \mathrm{of}$ the site to a total depth of $1,182 \mathrm{~m}(3,877 \mathrm{ft})$ in 1990 . None of the above-mentioned wells, all of which are located within $65 \mathrm{~km}$ (40 mi) of the RWMS, reported any hydrocarbon shows (Garside et al., 1988; Hess, 1992).

Previous studies in southern Nye County and the NTS do not report the occurrence of coal, tar sand, or oil shale. As such, very low potential exists for these resources to lend themselves to human intrusion. However, limited access to the NTS has precluded extensive exploration and a more complex evaluation categorizing source rock, reservoir rock, thermal history, and potential migration could be the subject of future research. 


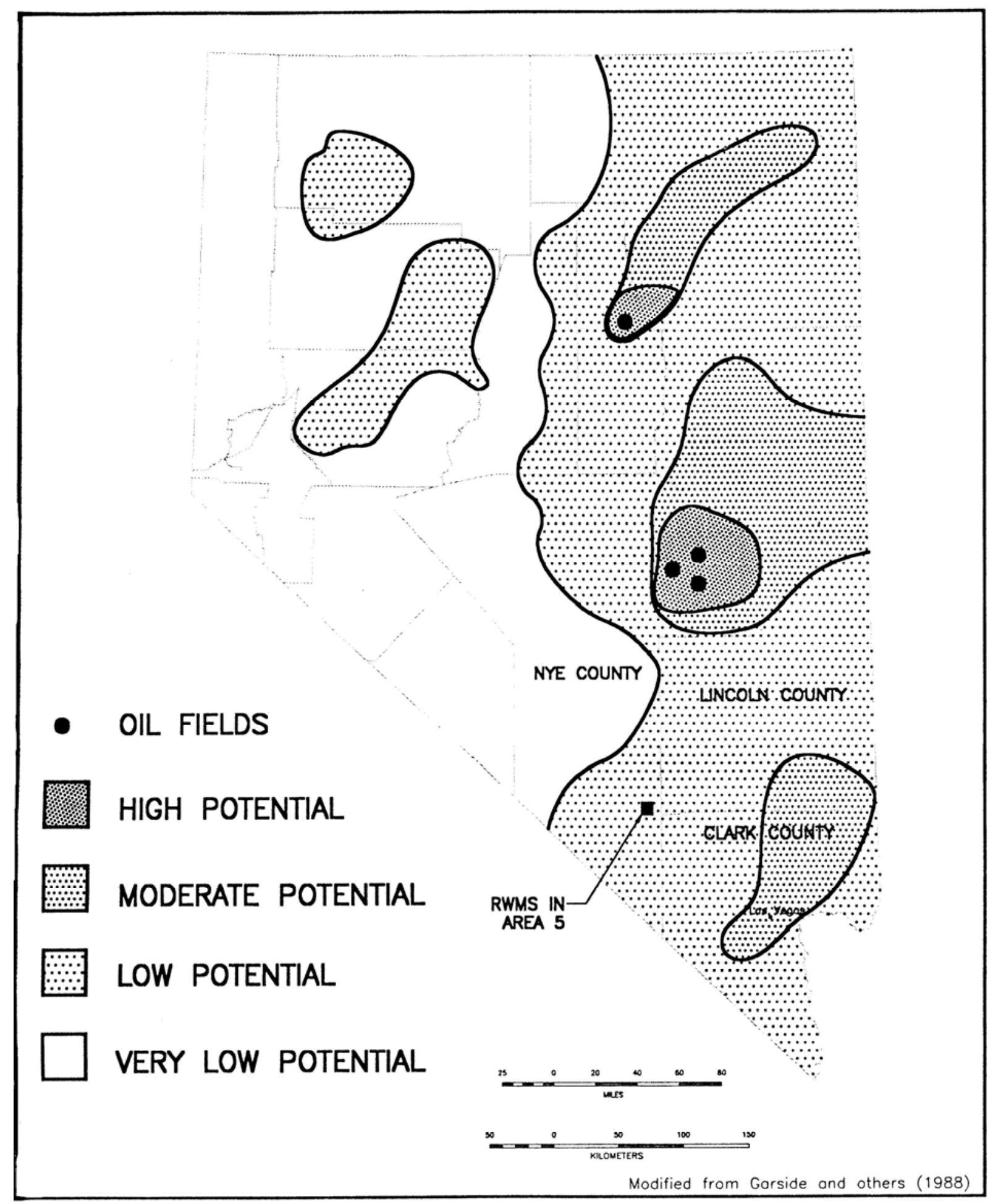

Figure 3

Nevada Petroleum Potential 
The DOE is currently evaluating Yucca Mountain, located approximately $48 \mathrm{~km}$ (30 mi) to the west of the RWMS, as a geologic repository for high-level radioactive waste. Johnson and Hummel (1991) postulate that the geologic setting at Yucca Mountain may be similar to the highly prolific overthrust belt in western Wyoming. Johnson and Hummel suggest that the current producing fields in Nevada may be the result of hydrocarbons migrating from deep thrust plates into shallow fault-block traps resulting from Tertiary extensional tectonics. A response to this theory was presented by Mattson et al. (1992). They concluded:

The theory, supported by Johnson and Hummel, that a buried Mesozoic thrust belt extends from east-central Nevada into southern Nevada has mixed acceptance by geologists working in the region. Less accepted is that this thrust places thermally mature Paleozoic rocks over thermally immature Paleozoic rocks. Theories that such a configuration would extend the structural trend for hydrocarbon production in the Railroad Valley area of northern Nye County into southern Nevada are highly speculative and not supported by information from drill holes in the state or most structural interpretations. Further, no overthrust plays of this type have been recognized in Nevada.

\subsection{WATER RESOURCES}

The saturated and unsaturated zones of the alluvial aquifer system in and around Area 5 of the NTS, Nye County, Nevada, consist of three major hydrostratigraphic units:

- Unconsolidated Quaternary and Tertiary valley fill,

- Tertiary volcanic ash and lava flows, and

- Paleozoic carbonate basement rock.

Pilot wells surrounding the RWMS indicate that the water table is approximately $237 \mathrm{~m}$ (770 $\mathrm{ft}$ ) below the ground surface (REECo, 1993) and is relatively flat. Case et al. (1984) located the water table at approximately $244 \mathrm{~m}$ (793 ft) below the land surface at the RWMS; although Winograd and Thordarson (1975) state that the water table occurs at depths ranging from 158 to $358 \mathrm{~m}$ (518 to 1,176 ft) beneath Frenchman Flat. The variations in the reported water table depths can be attributed to well-location distribution throughout the basin and the measurement method used to determine depth to the water table. In addition, perched water at depths as shallow as $21 \mathrm{~m}$ (70 ft) is present within tuff and lava flow aquifers in the southwestern part of the basin.

Initial sampling of groundwater from the pilot wells surrounding the RWMS indicates that it is good quality and meets all standards for hazardous and radioactive constituent. Past analyses by the Desert Research Institute (DRI) characterize the groundwater as sodium bicarbonate waters, saturated with respect to calcite, dolomite, and several forms of silicates (REECo, 1993).

Provided that the aquifer was accessible and the water is present in sufficient quantity, it has at least three potential uses: agricultural irrigation, commercial geothermal energy development, and human consumption. 
Agricultural irrigation at present is not a practical consideration for two reasons. First, the land in the area has soils with severe limitations that restrict the crop choice and/or require special practices and management (Case et al., 1984; Richard-Haggard, 1983). Second, water use in Nevada is strictly governed by the Office of the State Engineer and the Division of Natural Resources. The state of Nevada utilizes a recharge-use philosophy in managing groundwater resources so that total withdrawals do not exceed perennial yield. More often than not, overdraft occurs before the yield is established. In light of these existing regulatory constraints, at present, agricultural irrigation is possible but not probable. However, regulations are likely to change as the result of future needs and advancing technologies.

Commercial geothermal energy development is another potential water use. Assuming the lowtemperature geothermal resources present near Yucca Mountain (50 to 60 degrees Celsius $\left({ }^{\circ} \mathrm{C}\right.$ ) (140 to 160 degrees Fahrenheit $\left[{ }^{\circ} \mathrm{F}\right]$ ) are representative of the area, the use of the resource for energy development is highly unlikely. Current technology requires reservoir temperatures of at least $180^{\circ} \mathrm{C}\left(356^{\circ} \mathrm{F}\right)$ for commercial power; hence the potential for geothermal energy development appears very restricted (DOE, 1988). Any potential low-level application could be the subject of future research.

Human consumption of water has the most potential for cause of intrusion. As the Colorado River allocation to Nevada is fully utilized in the Las Vegas area, future growth in the state will need to be supported through water conservation, mining of conventional groundwater sources, and/or importing from other valleys in the state.

Development of deep carbonate aquifers has been suggested as an alternative source of water. One-third of the state of Nevada is underlain by deep carbonate rocks. These carbonate rocks are part of the Great Basin Carbonate Rock Province (Figure 4) which extends northeast from southern California, through eastern Nevada and western Utah, and into southern Idaho.

The incentive is becoming sufficiently strong to explore and evaluate deep carbonate aquifers. Evaluation and development of these deep carbonate aquifers are at present expensive, but as other sources of groundwater become depleted, the economics of developing deep carbonate aquifers may become less costly than importing water or reclaiming wastewater (Hess and Mifflin, 1978). Although development of these deep carbonate aquifers may not be of significant importance at the present, future water needs of the state may create a demand for their use as a water resource.

Movement of groundwater through the deep carbonate aquifer beneath the NTS consolidates several smaller topographic groundwater basins, including Frenchman Flat, into the larger Ash Meadows Groundwater Basin. Rate of flow through this carbonate aquifer is estimated at $3 \mathrm{~m} /$ year (10 ft/year). Estimated time of travel for water to move in the deep carbonate aquifer from Area 5 to the Ash Meadows discharge area is 3,800 years (Case et al., 1984).

Winograd and Thordarson (1975) estimated that 289,873 cubic meters (235 million acre-feet) of groundwater may be stored and slowly moving through the deep carbonate aquifer beneath the NTS. At 1978 consumption rates, this was estimated to be capable of providing water to the state of Nevada for approximately 40 years. Determination and revision of estimates for water consumption rates are not within the scope of this investigation. 


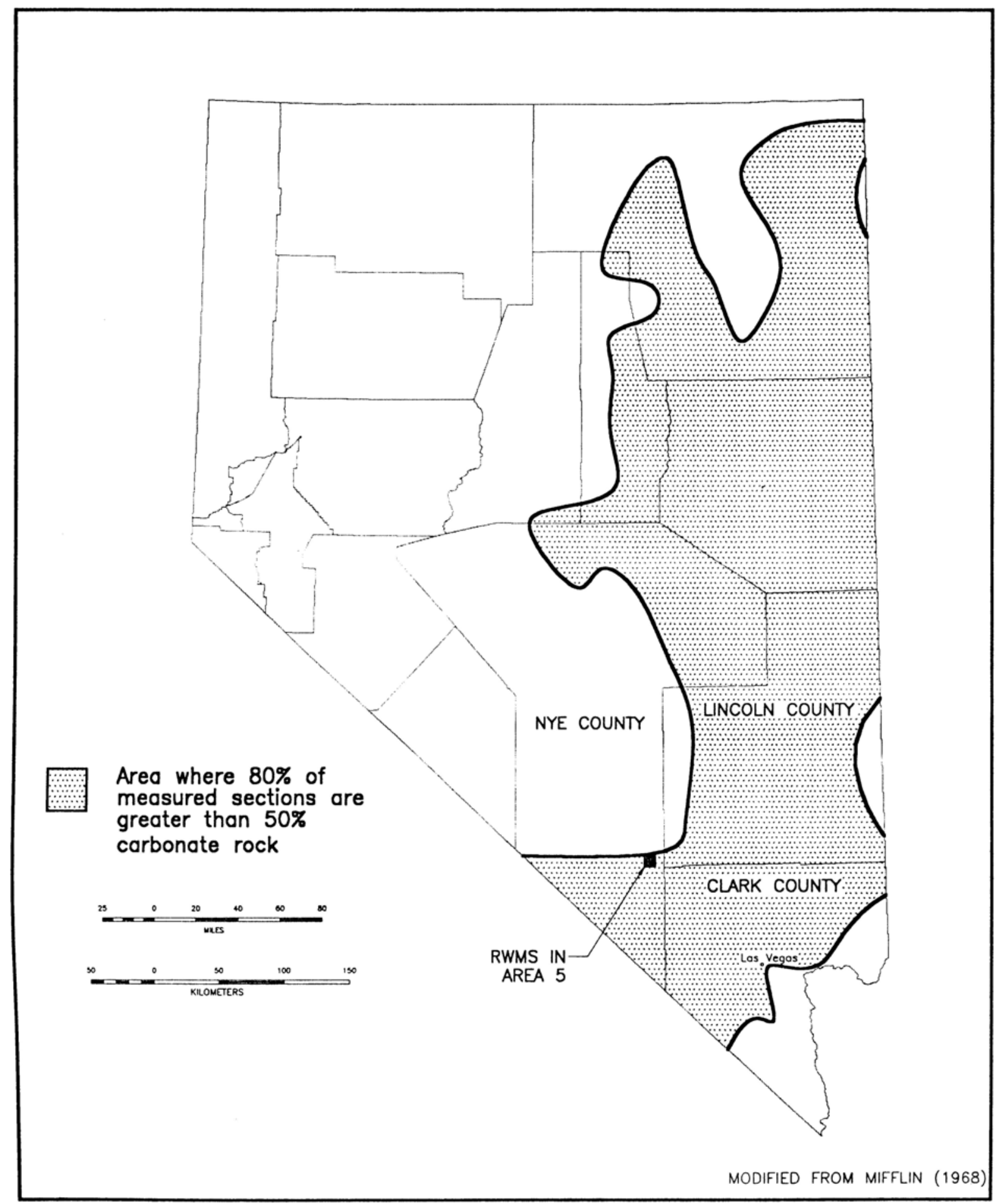

Note: Best available copy

Figure 4

Great Basin Carbonate Rock Province 
Well siting to extract underground water is often dependent upon the price of alternative water sources, expected yields, proximity to water users, well installation costs and long-term energy costs to pump the water, water rights, and water quality. Recharge areas along the mountain fronts, highly fractured parts of the aquifer, and areas where depth to water is small compared to the saturated thickness and potential yield, may be more attractive drilling sites than in the middle of Frenchman Flat, near the Area 5 RWMS.

\subsection{ALTERNATIVE ECONOMIC USES}

In 1983 and 1984, the DRI studied alternative economic uses of the land, minerals, and wild animal populations at the NTS to determine the potential for human intrusion at the site. They concluded:

The [entire] NTS has potential for mining, agriculture, grazing, and hunting as alternate land uses. The maximum economic potential, not counting mining, is roughly $\$ 442,000$ per year [1983 dollars]. The value of proven mineral resources is about $\$ 43,000$ [1983 dollars], but modern prospecting combined with modern methods of mineral recovery would in all likelihood increase the amount substantially. The potential for agriculture exists at the RWMS, but at the moment presents no incentive for actual development (Case and others, 1984).

Both Richard-Haggard (1983) and Case et al. (1984) concluded that their observations encompass the entire NTS and that the figures should be downscoped to reflect the RWMS alone. These authors also concluded that potential effects on the performance objectives of the RWMS are minimal because the location of animal herds, minerals, and possible grazing areas are not in Frenchman Flat or near the RWMS.

\subsection{REFERENCES}

Bechtel Nevada, 2005. A Hydrostratigraphic Model and Alternatives for the Groundwater Flow and Contaminant Transport Model of Corrective Action Unit 98: Frenchman Flat, Nye County, Nevada. DOE/NV/11718--1064. Las Vegas, NV. September 2005.

—, 2006. Characterization Report for the 92-Acre Area of the Area 5 Radioactive Waste Management Site, Nevada Test Site, Nevada. DOE/NV/11718--1154. Bechtel Nevada, Las Vegas, NV. June 2006.

BN, see Bechtel Nevada.

Case, C., J. Davis, R. French, and S. Raker, 1984. "Site Characterization in Connection with the Low Level Defense Waste Management Site in Area 5 of the Nevada Test Site, Nye County, Nevada-Final Report.” Publication No. 45034. Desert Research Institute, Las Vegas, NV.

Castor, S. B., S. C. Feldman, and J. V. Tingley, 1990. "Mineral Evaluation of the Yucca Mountain Addition, Nye County, Nevada.” Open File Report 90-4: Nevada Bureau Mines and Geology, Reno, NV. 80 p. + Appendices. 
Cornwall, H. R., 1972. “Geology and Mineral Deposits of Southern Nye County, NV.” Bulletin 77: Nevada Bureau of Mines and Geology, Reno, NV. 45 p.

Desotell, L. T., D. B. Hudson, V. Yucel, and J. T. Carilli, 2006. "Use of Long-Term Lysimeter Data in Support of Shallow Land Waste Disposal Cover Design.” In: Proceedings of the Waste Management '06 Conference, Tucson, Arizona, February 26 to March 2, 2006.

DOE, see U.S. Department of Energy.

Garside, L. J., R. H. Hess, K. L. Fleming, and B. S. Weimer, 1988. “Oil and Gas Developments in Nevada.” Bulletin 104: Nevada Bureau of Mines and Geology, Reno, NV. 47 p.

Gustafson, D. L., S. M. Parsons, and K. E. Snyder, 1993. “Greater Confinement Disposal Borehole Logging at the Area 5 Radioactive Waste Management Site, DOE Nevada Test Site, Nye County, Nevada.” Raytheon Services Nevada, Las Vegas, NV. 8 p.

Harris, A. G., B. R. Wardlaw, C. C. Rust, and G. K. Merrill, 1980. Maps for Assessing Thermal Maturity (Conodont Color Alteration Index Maps) in Ordovician through Triassic rocks in Nevada and Utah and Adjacent Parts of Idaho and California: U.S. Geological Survey Miscellaneous Investigations Series Map I-1249.

Hess, J. W., and M. D. Mifflin, 1978. “A Feasibility Study of Water Production from Deep Carbonate Aquifers in Nevada.” Desert Research Institute. Publication No. 41054. Las Vegas, NV.

Hess, R. H., 1992. “Oil and Gas Wells Drilled Since 1986.” NBMG Map 43. Nevada Bureau of Mines and Geology, Reno, NV.

Johnson, C., and P. Hummel, 1991. "Yucca Mountain, Nevada: Nuclear Waste or Resource Rich.” Geotimes, Vol. 36, No. 8, pp. 14-16.

Mattson, S. R., J. L. Younker, T. W. Bjerstedt, and J. R. Bergquist, 1992. “Assessing Yucca Mountain's Natural Resources.” Geotimes, Vol. 37, No. 1, pp. 18-20.

National Security Technologies, LLC, 2006. Nevada Test Site 2005 Waste Management Monitoring Report Area 3 and Area 5 Radioactive Waste Management Sites. DOE/NV/11718--1241. DOE/NV/25946--021. NSTec, Las Vegas, NV. August 2006.

NSTec, see National Security Technologies, LLC.

REECo, see Reynolds Electrical \& Engineering Co., Inc.

Reynolds Electrical \& Engineering Co., Inc., 1993. Hydrogeologic Data for Science Trench Boreholes at the Area 5 Radioactive Waste Management Site, Nye County, Nevada. DOE/NV/11432--32. Special Projects Section, Environmental Management Division, Reynolds Electrical \& Engineering Co., Inc., Las Vegas, NV. December 1993. 
Richard-Haggard, K., 1983. "Economic Potential of Alternative Land and Natural Resource Uses at the Nevada Test Site, Nye County, Nevada.” Publication No. 45030. Desert Research Institute, Las Vegas, NV.

Snyder, K. E., S. M. Parsons, and D. L. Gustafson, 1993. “Field Results of Subsurface Geologic Mapping at the Area 5 Radioactive Waste Management Site DOE/Nevada Test Site, Nye County, Nevada.” Raytheon Services Nevada, Las Vegas, NV. Paginated by section.

Stewart, J. H., and J. E. Carlson, 1978. Geologic Map of Nevada. Scale 1:500,000. U.S. Geological Survey.

U.S. Department of Energy, 1988. Site Characterization Plan: Yucca Mountain Site, Nevada Research and Development Area, Nevada. DOE/RW-0199. Office of Civilian Radioactive Waste Management, Washington, D.C. December 1988.

Winograd, I. J., and W. Thordarson, 1975. Hydrogeologic and Hydrochemical Framework, South-Central Great Basin, Nevada-California, with Special Reference to the Nevada Test Site. Geological Survey Professional Paper 712-C. U.S. Government Printing Office, Washington, D.C. 123 p. 
This Page Intentionally Left Blank 


\section{DISTRIBUTION}

U.S. Department of Energy

1 copy

National Nuclear Security Administration

Nevada Site Office

Technical Library

P.O. Box 98518

Las Vegas, NV 89193-8518

U.S. Department of Energy

1 copy

National Nuclear Security Administration

Nevada Site Office

Public Reading Facility, M/S 400

c/o Nuclear Testing Archive

P.O. Box 98521

Las Vegas, NV 89193-8521

U.S. Department of Energy

1 electronic copy

Office of Scientific and Technical Information

P.O. Box 62

Oak Ridge, TN 37831-0062

Renee Hudson

1 electronic copy

Environmental Management Library

National Security Technologies, LLC

P.O Box 98521, M/S NLV094

Las Vegas, NV 89193-8521 
This Page Intentionally Left Blank 


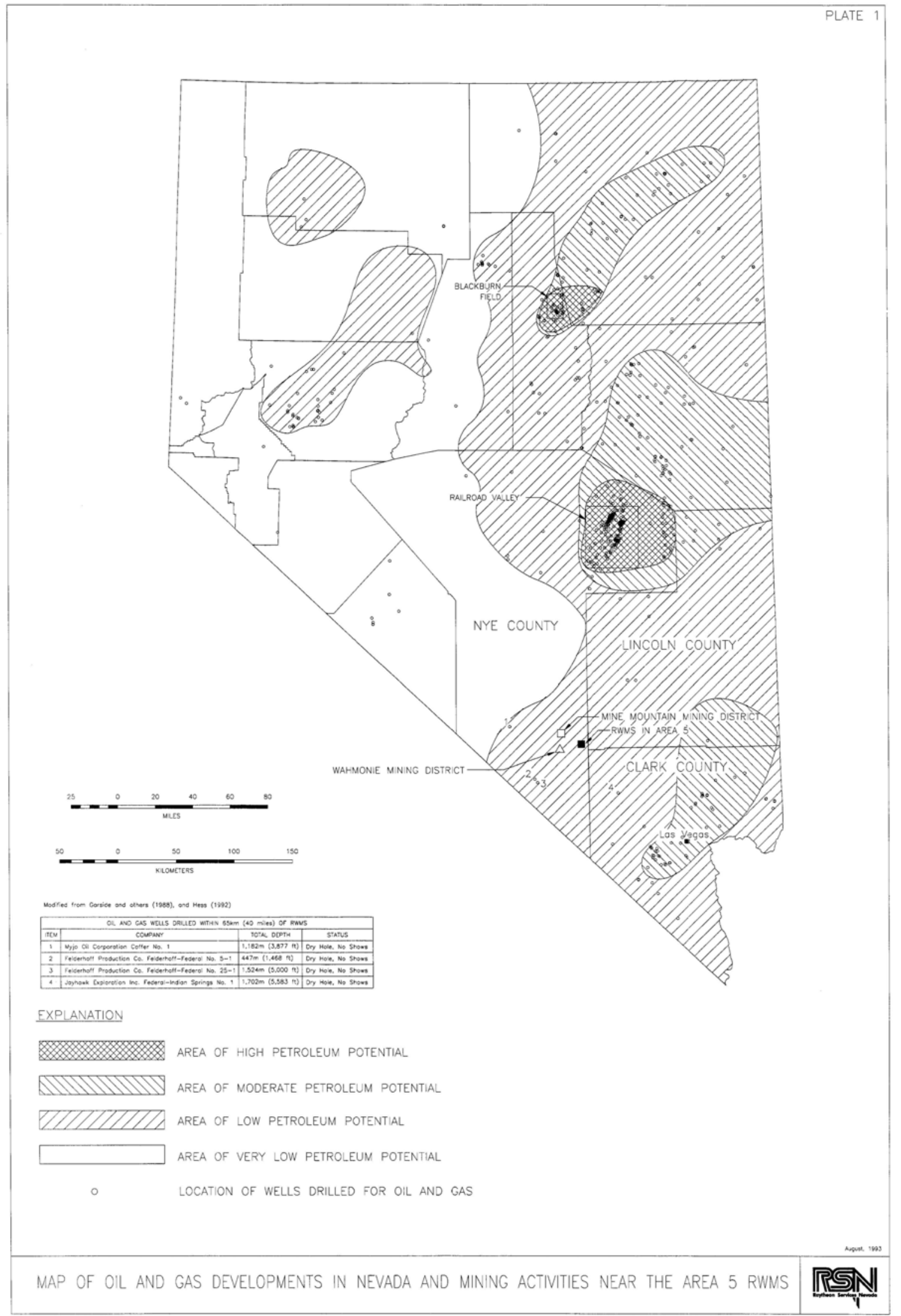

\section{Plate 1}

Map of Oil and Gas Developments in Nevada and Mining Activities Near the Area 5 RWMS 